\title{
GENERALIZATION AND SHARPNESS OF FINSLER-HADWIGER'S INEQUALITY AND ITS APPLICATIONS
}

\section{SHANHE WU}

Abstract. In this paper, the following generalization and sharpness of Finsler-Hadwiger's inequality is established

$$
\sum a^{\lambda} \geqslant 2^{\lambda} 3^{1-\frac{\lambda}{4}} F^{\frac{\lambda}{2}}+\sum|a-b|^{\lambda}+\sum_{n=1}^{m} \sum\left|a_{n}-b_{n}\right|^{\lambda} .
$$

As consequence, an exponential Finsler-Hadwiger type inequality for tetrahedron is derived.

Mathematics subject classification (2000): 26D15.

Key words and phrases: Finsler-Hadwiger's inequality, Weitzenböeck's inequality, power means inequality, triangle, tetrahedron.

\section{REFERENCES}

[1] O. BotTEMA, R. Z. DJoRdJEVIĆ, R. R. JANIĆ, D. S. MitrinoviĆ AND P. M. VASIĆ, Geometric Inequalities, Wolters-Noordhoff, Groningen, 1969.

[2] D. S. Mitrinović, J. E. PeČARIĆ AND V. VoleneC, Recent Advances in Geometric Inequalities, Kluwer Academic Publishers, Dordrecht, Netherlands, (1989), 104-106.

[3] D. S. Mitrinović, J. E. PeČArić, V. Volenec And J. Chen, Addenda to the Monograph: Recent Advances in Geometric Inequalities(I), Journal of Ningbo University, 4, (2) (1991), 80-81.

[4] Z. SHAN, Geometric Inequality in China, Jiangsu Education Publishing House, Nanjing, (1996), 82-86 (in Chinese).

[5] G. Hardy, J. E. LitTlewood AND G. Pólya, Inequalities, 2nd ed. Cambridge University Press, Cambridge, UK, 1952.

[6] S. H. WU, Generalization of some inequalities for tetrahedron, Journal of Longyan Teachers College, 21, (3) (2003), 8-12 (in Chinese). 